\title{
AL-QARADĀĀWI DAN ORIENTASI PEMIKIRAN HUKUM ISLAM UNTUK MENJAWAB TUNTUTAN PERUBAHAN SOSIAL
}

\author{
Badri Khaeruman \\ Dosen Fakultas Ushuluddin UIN Sunan Gunung Djati Bandung \\ Jl. A.H. Nasution 105 Cibiru, Bandung 40614, Indonesia. \\ E-mail: badrikhaeruman@gmail.com
}

\begin{abstract}
The appearance of Yüuf al-Qaradāwi, who is famous for his fatwas, seems to respond to the need of reform in Islamic legal thought in order for it to be more relevant. His works, such as Al-Ijtihād al-Mu'āsir baina al-Indhibāt wa al-Infirāt, Al-Halāl wa al-Harām fỉ al-Islām dan Min Hadyi al-Islām Fatāwa Mu'āshirah, shows his contribution to the development of Islamic legal thought today. Al-Qaradāwi says that the need for such a reform due to changes in almost all aspects of human life, where arise new issues that the legal status of which can not be found directly both in the scriptural texts and fatwas of religious scholars in the past. To reply the need of legal reform, al-Qaradāwi propossed two methods, namly intiqai (tarjīh of the existing fatwas) dan inshä (method to find out solutions for new issues that emerged in contemporary situation), with some requirements. In dealing with contemporary issues, his orientation of developing Islamic legal thought tends to be moderate between the two extreme ones, ifra (excessive) dan tafrit (oversimplipying). He holds the principle of "taysir (to provide comvenience)" and of "integration between legal views that are salafiah (scriptural) and renewal", which considers the social change not as a threat to the alienation of Islamic legal tought in the mids of public lives, but as a grace. In his legal perpective, the progress of science and technology that drive the various changes is synonymous with ease.
\end{abstract}

Keywords:

Social changes; new fatwa; al-Qaraḍ̄wi’s orientation of Islamis legal tought

\begin{abstract}
Abstrak
Kemunculan Yūsuf al-Qarậāwi, yang dikenal dengan fatwa-fatwanya, tampak merespon kebutuhan pembaruan pemikiran hukum Islam yang lebih sesuai dengan tuntutan zaman. Buku-bukunya seperti Al-Ijtihād al-Mu'āsir baina al-Indhibāt wa al-Infirāt, Al-Halāl wa al-Harām fì al-Islām dan Min Hadyi al-Islām Fatāwa Mu'āshirah, menunjukkan kontribusi beliau bagi pengembangan Hukum Islam dewasa ini. Kebutuhan pembaruan ini muncul seiring terjadinya perubahan dalam hampir segenap aspek kehidupan dimana muncul persoalan-persoalan baru yang status hukumnya tidak dapat ditemukan secara langsung baik dalam nash Kitab Suci maupun fatwa-fatwa ulama pada masa lalu. Dalam menjawab kebutuhan tersebut, al-Qaraḍāwi mengusulkan, antara lain, dua metode penggalian hukum, yakni intiqai (tarjīh atas fatwa-fatwa yang ada) dan inshäi (pengambilan pertimbangan hukum baru atas persoalan baru) dengan sejumlah persyaratan. Orientasi pemikiran hukumnya dalam menangani isu-isu kontemporer bersifat moderat di antara pendekatan ekstrim ifrät (berlebihan) dan tafrit (meremehkan), yakni dia menggunakan prinsip taysir (memberi kemudahan) dan "pemaduan antara pandangan yang bersifat salafiah dan pembaruan", yang menempatkan perubahan sosial bukan sebagai ancaman bagi terasingkannya hukum Islam di tengah-tengah kehidupan masyarakat, melainkan anugerah yang harus disyukuri. Dari perspektif hukumnya, kemajuan IPTEK yang mendorong pelbagai perubahan tersebut adalah identik dengan kemudahan.
\end{abstract}

Kata Kunci:

Perubahan sosial; fatwa hukum baru; orientasi pemikiran hukum Islam al-Qaraḍāwi.

DOI: http://dx.doi.org/10.15575/jw.v1i2.740

Received: April 2016 ; Accepted: October 2016 ; Published: November 2016

\section{A. PENDAhuluan}

Tak seorang pun mengingkari bahwa pesatnya perkembangan ilmu pengetahuan (sains) dan temuan-temuan teknologi di zaman modern ini telah mengakibatkan terjadinya perubahan sosial dalam kehidupan umat manusia, tak terkecuali umat Islam, baik di bidang kemasyarakatan, ekonomi, politik dan budaya. Seiring dengan perubahan sosial ini, muncullah permintaan fatwa Islam dari 
masyarakat luas dalam menghadapi pelbagai persoalan yang muncul dalam masyarakat modern.

Menurut al-Qaraḍāwi, kebutuhan akan fatwa bukanlah suatu tindakan main-main dan mengecilkan Islam. Dalam faktanya, sebagian orang menginginkan petunjuk Islam untuk kemudian diamalkan dalam kehidupan keseharian mereka yang bergelut dengan pelbagai bidang kehidupan modern, semisal dunia perbankan, asuransi, bisnis saham, transportasi, kesehatan, pengelolaan zakat dan lain sebagainya. Pandangan al-Qaradāwi ini memang cukup relevan terutama dalam kaitan dengan kebutuhan akan pemikiran baru yang betul-betul berbeda dengan fatwa-fatwa dan pemikiran fiqh yang lama. Pelbagai kemajuan ini telah menantang setiap pemikir Muslim untuk mengkaji ulang khazanah pemikiran klasik yang barangkali telah tidak sesuai dengan tuntutan kondisi saat ini. Dengan kata lain, sebagian dari khazanah pemikiran tersebut musti mampu mengikuti tuntutan keadaan, dan karenanya perlu dipilah mana di antaranya yang tidak lagi memadai atau bahkan harus diabaikan.

Perubahan 'illat (dalil) hukum, atau hilangnya 'illat hukum sama sekali, atau lahirnya 'illat hukum baru, dan pertimbangan-pertimbangan rasional terkait dengan penetapan suatu hukum atau fatwa merupakan faktorfaktor yang mendorong munculnya kebutuhan akan penafsiran baru atas teks-teks Shariat. Dasar atau alasan-alasan inilah yang kemudian memungkinkan pemahaman hukum atau fatwa hukum baru menjadi lebih variatif, tidak hanya satu pilihan saja, dan memungkinkan semuanya bisa dibenarkan dan sesuai dengan maqāsid al-shari' at.

Al-Qaradāwi, yang di tanah air dikenal dengan nama Yusuf Qaradhāwi, adalah ulama kontemporer, yang fatwanya sangat ditunggutunggu oleh masyarakat muslim internasional. Ulama kelahiran Mesir tahun 1926 dan kini masih hidup ini adalah ulama yang sangat produktif; ia telah menulis berbagai hal tentang Islam, tercatat lebih dari 20 buah judul buku yang telah dihasilkannya. Yang mengesankan dari Dewan Penyantun Pusat Studi
Keislaman di Universitas Oxford dan sejumlah organisasi Islam Internasional, baik yang berpusat di Timur Tengah maupun di Eropa dan Amerika Serikat saat ini, adalah fatwa-fatwa beliau yang mengisyaratkan pentingnya mengkaji kembali fatwa-fatwa ulama terdahulu demi menyelaraskannya dengan kebutuhan hidup umat hari ini.

Tulisan ini hendak mengeksplorasi bagaimana al-Qaraḍāwi menyikapi berbagai perubahan sosial sebagai dampak dari kemajuan sains dan teknologi yang memunculkan kebutuhan sosial akan rumusan hukum atau fatwa baru terkait dengan pelbagai persoalan kontemporer yang ditimbulkan perubahan tersebut; bagaimana metode yang digunakan alQardhāwi untuk menemukan hukum atau fatwa baru di tengah-tengah perubahan sosial; serta bagaimana orientasi pemikiran hukum Islam yang digagas al-Qaraḍāwi dalam menjawab tuntutan perubahan zaman tersebut.

\section{B. HASIL DAN PEMBAHASAN}

\section{Perubahan Sosial dan Tuntutan Pembaruan Hukum}

Istilah perubahan sosial di sini dipergunakan lebih dalam pengertian umum untuk menunjukkan bahhwa perubahan dalam persoalan sosial itu telah terjadi dalam rangka merespon kebutuhan-kebutuhan sosial itu sendiri. Salah satu kebutuhan sosial ini berhubungan dengan hukum, dan ini sangat terkait dengan dua aspek kerja hukum dalam hubungannya dengan perubahan sosial, yakni (1) hukum sebagai sarana kontrol sosial agar masyarakat bertingkah laku sesuai dengan harapan hukum yang sebenarnya; dan (2) hukum sebagai sarana kontrol rekayasa (engineering) untuk mencapai tata tertib hukum atau keadaan masyarakat yang sesuai dengan cita-cita dan perubahan yang diinginkan. ${ }^{1}$

Dalam konteks Islam, pembaruan hukum dalam rangka memenuhi tuntutan kebutuhan sosial ini berproses dengan kondisi dan situasi serta dengan tuntutan zaman. Hal ini

\footnotetext{
${ }^{1}$ Sodjono Dirdjosiswono, Sosiologi Hukum (Jakarta: CV. Rajawali, 1983), 76-77.
} 
disebabkan oleh karena norma-norma yang terkandung dalam kitab-kitab fiqh sudah tidak mampu lagi memberikan solusi terhadap berbagai masalah baru yang belum muncul pada masa kitab-kitab fiqh itu ditulis oleh para fuqaha. Dalam kasus seperti inilah sebuah ijtihad hukum diperlukan, dan salah satu bentuknya adalah pemberian fatwa. Berbagai pertanyaan berkenaan dengan berbagai masalah kehidupan dilontarkan kepada ulama atau mufti, baik secara lisan maupun tertulis, dan ulama atau mufti harus menjawabnya. Terlebih lagi jika tidak ada orang lain yang mampu menjawabnya selain dia, untuk saat yang dibutuhkan waktu itu. Jawaban ini tentu saja berangkat dari ijtihad. Dengan demikian, fatwa muncul untuk merespon realitas.

Para ulama' telah menjelaskan bahwa fatwa bisa berubah. Ini antara lain sejalan dengan teori qawl qadim dan qawl jadid yang dikemukakan oleh Imam Shafi'i, bahwa hukum juga dapat berubah, karena berubahnya dalil ('illat) hukum yang ditetapkan pada peristiwa tertentu dalam pelaksanaan maqāsid al-shari'ah. Perubahan hukum perlu dilaksanakan secara terus menerus karena hasil ijtihad selalu bersifat relatif, itulah sebabnya jawaban terhadap masalah baru senantiasa harus bersifat baru pula, asalkan tidak bertentangan dengan prinsip-prinsip Alquran dan Sunah. ${ }^{2}$

Konsep qawl qadim dan qawl jadid alShāfí' ${ }^{3}$ ini tampaknya juga menjadi pegangan al-Qaraḍāwi dalam memberikan fatwa-fatwa hukum. Bahkan al-Qaraḍāwi tampak

\footnotetext{
${ }^{2}$ Abdul Manan, Aspek-aspek Pengubah Hukum (Jakarta: Kencana, 2006), 226-227. Lihat juga, Sulis Syakhsiyah Annisa, "Hukum Islam dan Perubahan Sosial," 2009, diakses tanggal 14 Juni 2015, https://syakhsiyahwordpress.com/2009/08/12/110/ ftn8

${ }^{3}$ Istilah qawl qadim dan qawl jadid itu merupakan istilah yang dikemukakan sendiri oleh al-Syāfi'i, dengan istilah al-Risālah al-Qadìmah, untuk pendapatnya yang dinyatakan ketika beliau tinggal di Irak, dan pendapat-pendapat tersebut dikumpulkan dalam kitab al-Hujjah. Kitab ini diakui al-Shāfi'i sebagai kitab yang pertama yang ditulisnya sewaktu tinggal di Irak. Lihat Imām Al-Shāfi'i, al-Umm, ed. Mahmud Matraji, Jilid I, Cet. I, (Beirut: Dār al-Kutub al-Ilmiah, 2009), 31.
}

mengikuti apa yang telah dilakukan oleh 'Umar bin al-Khaththāb yang berpegang pada ruh Shari'at Islam, ${ }^{4}$ maupun pandangan alShāthibì yang berpegang pada maqăsid alshari'ah. ${ }^{5}$ Hal ini terlihat misalnya dalam memberikan fatwa tentang bolehnya wanita bepergian tanpa ditemani muhrimnya. Karena semula larangan itu adalah karena 'illat hukumnya berkaitan dengan keadaan sosial yang tidak menjami keamanan seorang perempuan. Namun sekarang kondisi sosial telah berubah dan terjamin keamanannya. Karena itu dengan sendirinya larangan bepergian itu harus berubah pula bersamaan dengan berubahnya 'illat hukum.

Demikian pula Al-Qaraḍāwi mengikuti jejak dan pemikiran Najm al-Dīn al-Thūfi yang berpegang pada maslahăt (kemaslahatan) ${ }^{6}$ dan berpegang kepada Ibnu Qayyim al-Jauziyah ${ }^{7}$ tentang adanya perubahan kondisi sosial yang dipandang sebagai 'illat baru dalam menentukan suatu hukum. Hal ini terlihat dalam memberikan fatwa tentang asuransi maupun fatwa-fatwa lainnya yang betul-betul baru seperti tentang transpalansi organ tubuh manusia.

\footnotetext{
${ }^{4}$ Pemikiran Umar atau lebih dikenal dengan fiqh Umar ibn al-Khațab, lihat misalnya dalam Muhammad Abd al-'Azīz al- Halāwi, Fatāwa wa Aqdịāe Amīiril Mukminin 'Umar ibn al-Khattāb, terj. Zubeir Suryadi Abdullah (Surabaya: Risalah Gusti, 1999).

${ }^{5}$ Pengarang al-Muwāfaqāt dan al-'It ișam ini dikenal sebagai pakar maqāsid al-sharì'ah dan ujung tombak madzhab Māliki dalam mempertegas posisi maslahat dan mereformulasi konsep maslahah mursalah dan maqāshid al-shari' 'ah yang disandarkan kepada Imām Mālik. Istilah maqāshid al-sharī'ah menurut Wahbah al-Zuhaili, berarti nilai-nilai dan sasaransasaran syara' yang tersirat dalam segenap atau bagian besar dari hukum-hukumnya. Nilai-nilai dan sasaransasaran itu dipandang sebagai tujuan dan rahasia shari'at, yang ditetapkan oleh Shāri' dalam setiap ketentuan hukum, lihat Wahbah Al-Zuhaili, Ushūl alFiqh al-Islāmi (Beirut: Dār al-Fikr, 1986). juz II, h. 1017

${ }^{6}$ Tesis al-Thüfi tentang bolehnya merubah hukum dengan alasan demi meraih maslahat, lihat dalam risalahnya: Al-Ṭ̂û́, Risalah fí Ri'àyat al-Maslahah, ed. Ahmad Abd al-Rahīm Sayikh (Mesir: al-Dār alMisriyah al-Lubnaniyah, 1993).

${ }^{7}$ Ibn Qayyim Al-Jauziyah, I'lām al-Muwāqi'īn 'an Rabb al-'Ālamīn, Jilid III, (Beirut: Dar al-Fikr, 1977).
} 


\section{Respon Al-Qaraḍāwi atas Kemajuan Iptek}

Dalam fatwa kontemporernya, terutama terkait dengan perubahan kemajuan ilmu pengetahuan dan teknologi, al-Qaraḍāwi ${ }^{8}$ memberi ilustrasi pemikiran bahwa prestasi ilmiah yang diraih dalam dunia sains dan teknologi pada abad ini telah berkembang pesat di setiap level. Kegemilangan-kegemilangan ini terealisasi justru ketika sebagian orang mengira bahwa hal itu merupakan sesuatu yang mustahil.

Di antara keberhasilan-keberhasilan penting yang diraih oleh manusia adalah terciptanya radio, yang kehadirannya mencengangkan orang. Bagaimana mungkin seseorang dapat mendengar suara orang lain, sementara antara mereka dipisahkan oleh lautan, pegunungan, lembah, padang pasir, yang jaraknya ribuan kilo meter.

Ketercengangan mereka semakin bertambah dengan terciptanya televisi, yang suaranya bisa didengarkan sekaligus dilihat gambar pengucapnya. Pada mulanya, televisi hadir dengan layar hitam putih, lalu berkembang menjadi berwarna. Setelah itu dilanjutkan dengan hadirnya perangkat satelit di dunia pertelevisian. Temuan teknologi semacam TV ini tidaklah sepi dari perdebatan hukum fiqhnya. Sebagian pihak mengharamkan tayangan TV untuk ditonton karena di dalamnya terdapat gambar-gambar. Namun, larangan tersebut, menurut pihak lain, justru akan membuat umat tertinggal dalam mendapatkan informasi.

Dalam bidang komunikasi, saluran-saluran komunikasi (telefon) di abad ini tidak lagi menggunakan kabel, sebagaimana sebelumnya. Umat manusia kini melihat handphone yang bisa dibawa ke mana-mana, ukurannya semakin mengecil sampai batas terkecil, dengan memberikan lebih banyak pelayanan. Bahkan terdapat pula telefon yang pemakainya bisa melihat wajah teman bicaranya. Temuan peralatan komunikasi ini juga bekontribusi

\footnotetext{
${ }^{8}$ Y ūsuf Al-Qaraḍ̄awi, Taysīir al-Fiqh li al-Muslim alMu'āshir (Kairo: Maktabah Wahbah, 1999)., 22. Lihat juga, Yūsuf Al-Qarạ̣āwi, Faktor-faktor Pengubah Fatwa (Jakarta: Pustaka al-Kautsar, 2009).
}

bagi perubahan fatwa hukum. Misalnya, dulu seseorang dilarang - menurut sebuat haditsuntuk pulang malam dari bepergian karena dapat mengagetkan istri, istri perlu persiapan, dan lain-lain. Dengan adanya HP dan sejenisnya seseorang bisa mengabarkan kepulangannya sehingga tidak masalah jika pulang waktu malam.

Manusia telah mampu berkomunikasi melalui teleks dan faksimile yang tak henti-hentinya berkembang. Ini semua merupakan salah satu dari tanda-tanda kebesaran Allah Swt. Selain itu masih banyak lagi ragam keajaiban komunikasi, hingga disebut sebagai "revolusi komunikasi". Dalam dunia komunikasi ini, terakhir lahir suatu jaringan komunikasi yang dinamakan dengan internet. Temuan-temuan ini juga, misalnya, dapat mengubah tradisi akad (transaksi) perdagangan yang sebelumnya dibatasi melalui perjumpaan langsung antara penjual dan pembeli dengan berjabatan tangan (al-qabdh). Dengan temuan telepon, internet, dan faksimile, transaksi tersebut kini dapat dilakukan tanpa pertemuan langsung pembeli-penjual, kebolehan transaksi melalu cek menjadi dapat diterima.

Dalam dunia kedokteran, pun terjadi kemajuan yang tidak kalah pesat. Khususnya dalam ilmu operasi dan bedah, lebih spesifik lagi pada teknik operasi hati dan mata yang telah menggunakan laser. Tidak hanya itu, bidang kedokteran sudah mampu melakukan transplantasi anggota tubuh, dari mulai ginjal, jantung, hati, kornea, hingga anggota tubuh lainnya. Ilmu kedokteran juga menemukan untuk pertama kalinya bayi tabung dan penyakit AIDS. Perubahan kemampuan seperti dalam bidang ini juga bisa menyebabkan perubahan dalam hukum.

Adapun di dunia obat-obatan, telah tercipta plasma darah dan injeksi yang banyak membantu menyembuhkan orang dari berbagai penyakit. Selain itu ada juga jenis obat-obatan yang sekadar digunakan untuk kekebalan tubuh, seperti untuk penyakit cacar. Dunia obat-obatan telah mampu menciptakan pil KB dan pinicilin. Pinicilin adalah suatu obat antibiotik yang dalam perkembangannya mempunyai pengaruh terhadap kemajuan di bidang 
operasi bedah. Demikian pula telah diciptakan jenis obat peredam rasa sakit, seperti aspirin dan sejenisnya, juga penenang rasa sakit perut (mulas) dan tulang.

Penemuan ini telah menciptakan sebuah revolusi global di dunia perindustrian dan pola hidup secara umum. Dengan temuan komputer, pesawat-pesawat beterbangan, roket-roket berluncuran, satelit-satelit buatan terus berputar, dan pesawat luar angkasa melesat jauh ke langit, hingga urusan kehidupan hampirhampir tidak bisa lepas dari revolusi elektronik, dan sampai anak-anak pun tidak ketinggalan turut menikmatinya. Kini, sistem pendidikan modern telah mewajibkan pengajaran komputer pada sekolah-sekolah dasar.

Di samping revolusi teknologi, astronomi, komunikasi, kedokteran, elektronik, terdapat pula revolusi lain yaitu revolusi biologi. Revolusi ini meliputi rekayasa genetika dan penentuan janin. Dengan revolusi biologi ini, mereka mampu menentukan apakah jenis kelamin janin yang berada dalam kandungan itu laki-laki ataukah perempuan. Barangkali juga mampu menentukan bentuk dan wajahnya, berkulit hitamkah atau putih, rambutnya lurus atau ikal, kedua matanya biru atau hitam, dan sebagainya, sampa-sampai sebagian orang menyebutnya sebagai "bayi sesuai katalog". Kemampuan teknologi untuk mengetahui keberadaan Janin dalam kandungan juga turut melahirkan perubahan hukum, seperti yang terkait dengan hitungan masa iddah (penantian) perempuan yang dicerai suami.

Puncak prestasi dalam bidang biologi ini berakhir pada "kloning hewan", sebagaimana pernah dilakukan pada seekor biri-biri betina yang kemudian terkenal dengan nama Dolly. Peristiwa ini menjadi menakutkan jika terus berkembang ke kloning manusia. Inilah yang diperingatkan oleh para pakar agama, akhlak, sosial, dan hukum, karena praktek kloning itu membawa madarat dan bahaya. ${ }^{9}$

Masih ada lagi revolusi lain, yang dinamakan "revolusi informasi". Kita sekarang berada pada era "ledakan ilmu pengetahuan" di mana kuantitas pengetahuan yang kita terima

\footnotetext{
${ }^{9}$ Al-Qaraḍ̄āi, Taysir al-Fiqh li al-Muslim alMu'āshir, 26.
}

menjadi tak terhitung kadarnya yang pada akhirnya mengharuskan kita untuk membuat bab-bab dan daftar isi yang sesuai dengan bidangnya.

Revolusi-revolusi ini telah menghasilkan berbagai macam hal yang menguntungkan: kesejahteraan hidup, efesiensi tempat dan waktu, memperpendek jarak, penghematan waktu dan tenaga, kemudahan transpontasi, cara mendapatkan kenyamanan seperti AC di musim panas, penghangat ruangan di musim dingin, pendingin dan pemanas air sesuai kebutuhan, hadirnya mesin cuci dan oven elektrik, microwave, mesin-mesin pembersih, dan sebagainya. Di daerah-daerah bercuaca panas, AC menjadi kebutuhan primer dan karenanya menjadi pengurang nișab zakat sebagaimana kebutuhan-kebutuhan pokok lainnya, sebab zakat merupakan kelebihan dari kebutuhan pokok. Begitupun laptop bagi guru tidak sama tingkat kebutuhannya dengan laptop bagi petani seperti traktor yang menjadi kebalikannya. Ini juga bisa berkaitan dengan penentuan hukum niṣab zakat.

Di samping itu semua, perubahan situasi sosial, ekonomi, dan politik juga dapat menjadi faktor pengubah fatwa. Ketika kondisi politik tidak menguntungkan kaum muslimin dengan berkuasanya rezim otoriter yang memusuhi Islam. Dalam kondisi seperti itu, seorang ulama perlu memikirkan akibat fatwanya bagi umat Islam, ketika ia diminta fatwa secara terbuka. Jangan sampai fatwanya tersebut malah mengancam kondisi umat Islam dan gerakan dakwah Islam.

\section{Metode Pembaruan Hukum Yusuf al- Qaraḍāwi}

Sebagaimana telah kita lihat, pelbagai perubahan yang berlangsung dalam pelbagai bidang kehidupan menusia menjadi faktor yang mendorong adanya kebutuhan akan fatwa-fatwa hukum baru. Al-Qaradāwi menyebutkan beberapa jenis berubahan ini, antara lain: perubahan tempat, waktu, kondisi, tradisi, pengaruh sains, kebutuhan manusia modern, sosial, politik dan ekonomi.

Menurut DR Yūsuf al-Qaraḍ̄âi ada dua metode yang tepat dan cocok digunakan untuk 
dilaksanakan dalam menghadapi era globalisasi saat ini. Pertama, ijtihäd intiq $\overline{a i}{ }^{10}$ yakni meneliti ulang hasil ijtihad para ulama dahulu dan secara komprehensif membandingkan dan mengambil pendapat yang kuat sesuai dengan kriteria dan kaidah tarjîh dan tolok-ukurnya. Alat ukur pentarjīhan selain dalil yang kuat, juga disyaratkan: (1) sesuai dengan jaman diberlakukannya, (2) sesuai dengan maksud rahmatan li al-'alamīn, (3) sesuai dengan prinsip taysir (memberi-kemudahan), dan (4) sesuai dengan kemaslahatan.

Kedua, ijtihad inshai, ${ }^{11}$ yakni mengambil konklusi pendapat baru dalam persoalan baru yang belum pernah dikemukakan oleh mujtahid lain. Seperti dalam menghadapi masalah pentingnya penggunaan foto sebagai identitas diri, sementara terdapat anggapan bahwa foto itu gambar, dan karenanya terlarang berdasarkan sebuah hadits tentang larangan membuat gambar. Pandangan baru mengatakan bahwa foto itu bukanlah gambar yang dilarang. Larangan Nabi atas pembuatan gambar terkait dengan pembandingan gambar tersebut dengan makhluk Allah. Sedang foto adalah bayangan refleksi seperti dalam kaca, yang kemudian direfleksikan dalam kertas melalui alat modern.

Mengahadap tutuntan jaman, persoalanpersoalan yang muncul, dan perelisihan bebagai mazhab, maka agar efektif dan menghasilkan suatu hukum, pelaksanaan ijtihad

الاجتهاد الانتقائي: اختيار أحد الآراء المنقولة في تر اثنا الفقهي 10

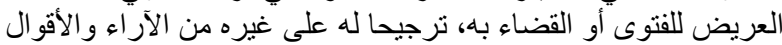

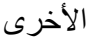

Memilih suatu pendapat dari beberapa pendapat terkuat yang terdapat pada warisan fiqh Islam.

أما الاجتهاد الإنشائي فنعني به: استنباط حكم جديد في مسألة من 11



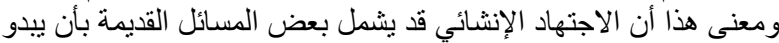

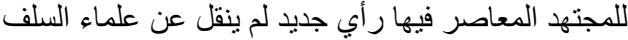

Adapun yang dimaksud dengan ijtihād inshā' $\vec{i}$ adalah pengambilan istinbāt hukum dari suatu persoalan yang baru, yang belum pernah dikemukakan oleh ulama terdahulu, baik istinbàt itu menyangkut masalah lama (dengan 'illat baru) atau masalah yang betul-betul baru. Itulah yang dimaksud ijtihād insha $\bar{i} \bar{i}$, yang mencakup persoalan lama di mana seseorang mujtahid kontemporer bekerja keras untuk mendapat istinbăt hukum yang baru, yang belum ditemukan di dalam pendapat ulama salaf. inshä dalam menyelesaikan suatu masalah perlu dilakukan secara kolektif (jamá'i). Ijtihad jamā'i memiliki urgensi yang sangat tinggi dalam pembaharuan hukum Islam yang diperlukan umat islam pada abad modern ini. Salah satu urgensi ijtihad jamā'i ini adalah penerapan prinsip shüra.

\section{Al-Qaradāwi dan Orientasi Pemikiran Hukum Islam untuk Menjawab Tuntutan Perubahan Sosial}

Orientasi pemikiran hukum Islam dalam menjawab persoalan-persoalan kontemporer, yang dikemukakan oleh al-Qaraḍ̄āi dengan istilah Fiqh Jadid, bercirikan metode-metode fiqh berikut: ${ }^{13}$

a) Fiqh al-Muwāzanah (Fiqh keseimbangan), metode yang dilakukan dalam mengambil keputusan hukum, pada saat terjadinya pertentangan dilematis antara maslahat dan mafsadat, atau antara kebaikan dan keburukan. Menurutnya, sebuah kemadaratan kecil boleh dilakukan untuk mendapatkan kemaslahatan yang lebih besar, atau kerusakan temporer boleh dilakukan untuk mempertahankan kemaslahatan yang kekal, bahkan kerusakan besar pun dapat dipertahankan jika dengan menghilangkannya akan menimbulkan kerusakan yang lebih besar.

b) Fiqh Wāqi' (Fiqh realitas), metode yang digunakan untuk memahami realitas dan persoalan-persoalan yang muncul di hadapan umat, sehingga dapat menerapkan hukum sesuai tuntutan zaman.

c) Fiqh al-Aulāwiyāt (Fiqh Prioritas), metode untuk menyusun sebuah sistem dalam menilai sebuah pekerjaan, mana yang seharusnya didahulukan atau diakhirkan. Salah satunya adalah bagaimana mendahulukan Ushül daripada furü, mendahulukan ikatan Islam dari ikatan lainnya, ilmu pengetahuan sebelum beramal, kualitas daripada kuantitas,

\footnotetext{
${ }^{12}$ Abdul Manan, Aspek-aspek Pengubah Hukum, 218.

${ }^{13}$ Dikemukakan oleh M Siddiq, "Menyoal fiqih Waqi Fikih Realitas," 2010, diakses tanggal 15 September 2015, http://syabab1924.blogspot.co.id/ 2010/09/menyoal-fiqih-waqi-fikih-realitas.html..
} 
agama daripada jiwa serta mendahulukan tarbiyah sebelum berjihad.

d) Fiqh al-Maqāsid al-Shari' at, metode ini ditujukan bagaimana memahami nash-nash shar'i yang juz'i dalam konteks maqāsid alshari' 'at dan mengikatkan sebuah hukum dengan tujuan utama ditetapkannya hukum tersebut untuk melindungi kemaslahatan bagi seluruh manusia, baik dunia maupun akhirat.

e) Fiqh al-Taghyir (Fiqh perubahan), metode untuk melakukan perubahan terhadap tatanan masyarakat yang tidak Islami dan mendorong masyarakat untuk melakukan perubahan.

Kelima orientasi hukum Islam yang sangat luwes, yang menekankan prinsip kemudahan dan keringanan tersebut, dinilai oleh banyak ahli sebagai gagasan asli Yūsuf Al-Qaraḍ̄wi dalam upayanya melakukan pembaruan pemikiran hukum, terutama dalam upaya menyikapi perubahan kemajuan zaman dewasa ini. Dalam Fiqh Wāqi' misalnya, al-Qaraḍāwi (1997) menjelaskan bahwa fiqh wäqi' ialah pengetahuan mengenai realitas yang sebenarnya, baik yang menguntungkan maupun yang merugikan. Realitas ini penting dipahami karena, menurutnya, pemahaman atas realitas akan menjadi pertimbangan tentang bagaimana kita berhubungan dengan realitas: apakah realitas itu akan kita terima atau kita tolak?

Menurut al-Qaraḍ̄wi, dalam Sirah Nabi Saw kita akan menemukan hukum yang tidak sama penerapannya dalam berbagai situasi, yang terjadi karena perbedaan realitas yang melatarbelakanginya. Misalnya, sikap Nabi Saw. yang keras terhadap Yahudi Bani Quraizhah dengan sikap beliau yang lembut terhadap kaum musyrik Makkah saat fathu Makkah (kemenangan atas Makkah). Karena itu, menurut al-Qaradāwi, para ulama menetapkan bahwa fatwa itu bisa berubah karena perubahan zaman, tempat, keadaan, dan adat-istiadat, sebagaimana kaidah yang dikemukakan oleh Ibn al-Qayyim alJauziyah. $^{14}$ Latar belakang prinsip hukum

14 Kaidah yang dimaksud: وبتيّر الفتوى بتغيّر الأزمنة و الأمكنة و الأحو ال و العو ائد و النيّات (Lihat Ibn Qayyim AlJauziyah, I'lām al-Muwāqi' ìn 'an Rabb al-'ÁAlaminn, 14. yang menekankan kemudahan dan keringanan ini, menurut al-Qaraḍāwi, adalah bahwa sejak tahun 1950-an dan 1960-an, telah terjadi dua aliran paham yang tidak menguntungkan bagi upaya kebangkitan umat: pada satu sisi ada sikap berlebihan (ifrạt), sedangkan pada sisi lain ada sikap meremehkan (tafrịt). Sikap berlebihan, misalnya, tidak mengakui pendapat lain, keras, dan suka mengkafirkan. Sebaliknya, sikap meremehkan ialah sikap kaum liberal yang berfatwa tanpa landasan agama dan hanya mengikuti hawa nafsu. Karena itulah, perlu dihidupkan prinsip moderat (tawassuth) yang berintikan dua prinsip: (1) berasaskan kemudahan (taysir) dan kabar gembira; (2) perpaduan salafiyah dan pembaruan (tajdid). Maksud salafiyah adalah mengikuti sumber pokok, yakni Alquran dan Sunah; sedangkan pembaruan, maksudnya, adalah menyatu dan mengikuti zaman, tidak jumud (beku) atau taklid buta. Dalam rangka pembaruan itu, digagaslah fiqh al-wäqi .

Menurut M. Siddiq (2010), ${ }^{15}$ bahwa landasan fiqh al-wāqi ' dapat dicermati dari manhaj Al-Qaradāwi dalam berfatwa, yang diuraikannya dalam Al-Fatwa bayna al-Indhibạt wa alTasayyub, 1994. Dapat dilihat juga dari segi ushul fikihnya dalam kitab Taysir al-Fiqh li al-Muslim al-Mu'āshir, 1999. Manhaj alQaraḍāwi dalam berfatwa adalah: (1) melepaskan diri dari fanatisme mazhab dan taklid buta; (2) memberikan kemudahan (taysïr) dan keringanan (takhfif), bukan memberikan keketatan (tashdid) dan mempersulit (tas ' $\overline{\text { ir }}$ ); (3) berfatwa dengan bahasa yang populer; (4) tidak menyibukkan diri kecuali untuk hal-hal yang bermanfaat; (5) mengedepankan ruh moderat (tawassuth), antara ifrat dan tafrit;

(6) berfatwa dengan penjelasan dan sharh.

Dalam kitab Taysir al-Fiqh li al-Muslim alMu'āshir, al-Qaraḍ̄āi menjelaskan dalil-dalil syariat yang melandasi fatwanya. Selain berpegang dengan 4 (empat) dalil pokok (Alquran, Sunah, Ijma Sahabat, dan Qiyas), al-Qaraḍ̄āi juga berpegang dengan dalil alistihsān dan al-mashālih al-mursalah. AlQaraḍāwi berpegang pula pada kaidah,

\footnotetext{
${ }^{15}$ M. Siddiq, "Menyoal fiqih Waqi Fikih Realitas,"
} 
"Adanya perubahan fatwa berdasarkan berubahnya zaman, tempat, dan kondisi." Kaidah ini tampaknya sangat diutamakan dan ditonjolkan oleh al-Qaraḍāwi, yang bahkan secara khusus beliau jelaskan menjadi satu kitab tersendiri, yaitu kitab Keluasan dan Keluwesan Hukum Islam ('Awāmil al-Să'ah wa alMurūnah fî al-Sharī at al-Islämiyyah, 1993).

Orientasi pemikiran hukum Islam yang terkesan ringan dan mudah tersebut bukan tanpa kritik. Bahkan Ahmad ibn Muhammad ibn Mansūr al-' $\bar{A}$ dini, ulama salaf dari Yaman, mengkritik al-Qaraḍ̄âi dengan memakai judul buku yang tidak pantas: $R a f^{\prime} u$ al-Lithāmi 'an Mukhālafati al-Qaradāwi li Shari'at al-Islām, 2001, (Mengungkap Tabir Kebusukan Al-Qaradâwi dalam bukunya Syariat Islam). Sebelumnya, Sheikh Shalih ibn Fauzan dari Saudi Arabia, mengkritik buku al-Halāl wa al-Harām fí al-Islām karya al-Qaraḍāwi, dengan bukunya al-I'lām bi Naqd Kitāb al-Halāl wa al-Harām fí al-Islām, 1975.

Namun soal pro-kontra dalam dunia pemikiran nampaknya soal yang lumrah dan biasa. Bahkan pikiran-pikiran al-Qaraḍāwi banyak diterima dan juga fatwanya dinanti oleh dunia Islam Internasional. Al-Qaraḍāwi misalnya membenarkan sistem demokrasi dan tidak menganggapnya bertentangan dengan Islam, dan membolehkan bergabung dengan pemerintahan yang bukan Islam. Mengapa Islam dapat menerima demokrasi? Sebab, menurut al-Qarad̄āwi, substansi demokrasi adalah suatu proses pemilihan yang melibatkan orang banyak untuk mengangkat seseorang (kandidat) yang berhak memimpin dan mengurus keadaan mereka. Ini, menurutnya, sejalan dengan Islam, dan bahkan, berasal dari Islam itu sendiri. Sebab, Islam menolak seseorang menjadi imam shalat yang tidak disukai makmum. Jika dalam shalat saja demikian, apalagi dalam urusan politik. Prinsip kedaulatan rakyat, kata al-Qaraḍāwi, tidak mesti dipertentangkan dengan kedaulatan Allah, selama tidak ada pertentangan di antara keduanya.
Masih menurut M. Siddiq al-Jawi (2010), ${ }^{16}$ bolehnya bergabung dengan pemerintahan bukan Islam, menurut al-Qaraḍāwi, hukum dasarnya sebenarnya tidak boleh. Akan tetapi, al-Qaradāwi lalu keluar dari hukum dasar ini dan kemudian membolehkannya dengan syarat-syarat tertentu. Alasannya: (1) tuntutan meminimalkan kejahatan dan kezaliman adalah sesuai kesanggupan; (2) hal itu dilakukan untuk memilih kemadaratan yang paling ringan; (3) karena melepaskan nilai tertinggi lalu turun ke realitas terendah; (4) ada prinsip pentahapan (tadarruj).

Di kalangan umat Islam, ada yang mengharamkan demokrasi, seperti Taqiyuddin anNabhāni, Al-Maudūdi, dan Abdul Qadìm Zallum; ada pula menghalalkan demokrasi, seperti Fahmi Huwaidi, Sulaiman alThamāwì dan Abdul Hamid Mutawalli. AlQaraḍāwi cenderung pada yang mudah dan ringan, yakni yang menghalalkan demokrasi, yang sedang mendominasi realitas. Di kalangan umat ada ulama yang menghalalkan bergabung dengan sistem pemerintahan bukan Islam (yang menjadi realitas di tengah umat), ada pula ulama yang mengharamkannya. AlQaraḍāwi cenderung pada yang mudah dan gampang, yakni yang menghalalkannya, walaupun menurutnya pada dasarnya tidak boleh.

\section{Pengaruh Pemikiran Al-Qaraḍāwi bagi Pentingnya Peninjauan Kembali atas Sejumlah Ketentuan Syariat yang Berlaku Saat Ini}

Pengaruh pemikiran al-Qaraḍ̄awi terhadap sejumlah fatwa yang telah dibuatnya dengan metode intiqaī/tarjīh dan inshäi-nya, dalam berbagai persoalan yang perlu mendapat pengujian kembali, terutama terkait fatwafatwa ulama Indonesia, atau dalam menghadapi persoalan baru yang memerlukan fatwafatwa baru pula, dapat dicermati dalam rumusan-rumusan hukum atau fatwa-fawa yang ditetapkannya, antara lain, sebagai berikut:

\footnotetext{
${ }^{16}$ M. Siddiq, "Menyoal Fiqih Waqi Fikih Realitas"
} 


\section{a. Mengabaikan rukhsah karena tidak diperlukan lagi.}

Aturan tentang rukhsah (keringanan) yang ditetapkan Allah bagi musafir, seperti shalat bisa dijama' dan diqasar, serta wudhu bisa diganti dengan tayamum. Rukhșah ini berlaku jika memang perjalanan itu 'illat-nya seperti perjalanan yang terjadi di zaman Alquran turun, yang penuh dengan kesulitan. Jika perjalanan yang dilakukan oleh manusia modern dewasa ini yang dalam faktanya penuh dengan kemudahan-bisa sambil tidur dan setiap saat bisa istirahat di setiap tempatmaka tampak tidak ada 'illat yang bernama kesulitan itu, dan dengan begitu seharusnya hukumnya kembali ke asal.

Jika bepergian dianggap sebagai 'illat hukum, baik bepergian yang menyenangkan atau penuh kesulitan, sehingga bisa diberlakukan hukum rukhsah, maka tindakan ini dipandang tidak adil dan tidak rasional. Sebab zaman lalu berbeda dengan sekarang. Zaman dulu bepergian itu identik dengan adanya unsur kesulitan, sementara sekarang, zaman telah jauh berubah.

Demikian pula rukhsah bagi wanita yang melahirkan di mana pada zaman Rasul ditetapkan dan dibolehkan untuk meninggalkan shalat selama 40 hari. ${ }^{17}$ Jika ketetapan ini terus berlaku, maka tampaknya ketetapan ini tidak rasional, sebab penanganan kelahiran dewasa ini jauh lebih maju dibanding pada zaman Nabi.

\footnotetext{
${ }^{17}$ Lihat misalnya Hadits riwayat Ummu Salamah yang menyatakan:

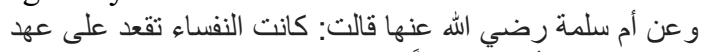

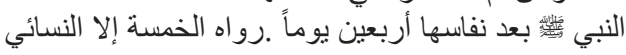

"Wanita-wanita yang sedang nifas pada masa Nabi Saw meninggalkan shalat selama 40 hari. Riwayat Imam yang lima kecuali al-Nasāi. Dalam lafzah Abu Dawud, dinyatakan bahwa Nabi Saw tidak memerintahkan wanita-wanita nifas itu untuk mengqadha shalat yang ditinggalkan selama masa nifas. (Lihat Muhammad bin Ali Al-Syaukānì, "hadits No. 390," t.t.
}

\section{b. Peninjauan kembali ketentuan membayar zakat fitrah.}

Masyarakat Muslim Indonesia secara tradisi, yang mungkin merupakan fatwa ulama tempo dulu, membayar zakat fitrah dengan ukuran beras, sebagai qiyas dari makanan pokok gandum. Pengiyasan seperti itu dipandang kurang tepat karena yang dinyatakan dalam teks shari'at zakat fitrah itu terlebih dahulu disebutkan dengan kurma, seperti Hadit Nabi menyatakan:

“Zakat fitrah itu satu șa' kurma, atau satu sa'ṣa'ir dari setiap kepala, atau satu șa' bur atau gandum antara dua orang..." (Riwayat Ahmad dan Abū Dāwud dari Abdullah bin Tha'labah).

Bahkan Hadith-hadith tentang zakat fitrah yang diriwayatkan dan dijadikan dasar hukum oleh Imam al-Shafi'i dalam memberikan fatwanya, tidak menyebutkan bahwa zakat fitrah itu dengan gandum, melainkan dengan makanan secara umum (ta'am).

Zakat fitrah dengan memakai ukuran kurma seperti dijelaskan dalam Hadits di atas, jelas akan membedakan nilai harganya, jika dibanding dengan memakai ukuran gandum. Harga kurma yang standar, tidak terlalu tinggi dan tidak terlalu rendah harganya, misalnya yang dijual di pasar-pasar di Indonesia yaitu: $50.000 / \mathrm{kg} \times 2,5 \mathrm{~kg}\left(1 \stackrel{s a^{\prime}}{ }\right)=125.000 /$ perorang, untuk setiap zakat fitrah. Sebaliknya, jika bersandar pada ukuran beras (gandum), adalah: $10.000 / \mathrm{kg}$ x 2,5 (1 sa') $=25.000 /$ perorang, untuk setiap zakat fitrah. Perbedaan ini jauh sekali, dan tentunya memiliki kadar paling rendah nilai 'ubudiyah-nya.

Alasan para ulama atas pengiyasan kepada beras dari gandum itu karena dipandang sebagai makanan pokok. Hal ini juga dipandang tidak tepat, sekalipun beras dan gandum memiliki kesamaan sebagai makanan pokok yang dapat mengenyangkan perut, tetapi makanan ini memerlukan makanan pendamping lainnya ketika dikonsumsi seperti lauk pauk dan sayuran, yang tentunya penyediaannya memerlukan biaya. Sementara jika diqiyaskan kepada kurma, yang sesungguhnya disebutkan paling awal dalam teks Hadits 
tersebut, maka makan kurma tidak memerlukan makanan pendamping lainnya, seperti ikan dan sayuran, ia hanya cukup ditemani oleh segelas air. Demikian pula nilai gizi yang dikandung kurma jauh lebih tinggi dibanding dengan yang terdapat dalam gandum.

Jadi, zakat fitrah dengan memakai ukuran kurma jauh lebih mendekatkan pada maqāsid al-shari'at zakat fitrah itu sendiri dibanding dengan zakat dengan memakai ukuran gandum. Apalagi sekarang berzakat fitrah dengan memakai ukuran kurma dan gandum sama-sama dalam praktiknya bisa dinilaikan kepada harga keduanya (diuangkan). Bukan dengan kedua jenis makanan itu sendiri.

\section{c. Peninjauan kembali ketentuan 'iddah wanita yang dicerai.}

Para ulama dengan segala otoritas yang dimilikinya telah menetapkan bahwa masa menunggu ('iddah) bagi wanita yang dicerai suaminya adalah 3 bulan. Ketetapan ini berdasarkan tafsiran dari kata qurü, yang diartikan dengan tiga kali suci dari menstruasi (hayd). Kata tersebut dinyatakan ayat: "Wanita-wanita yang dicerai hendaklah menahan diri (menunggu) tiga kali qurū'. Tidak boleh mereka menyembunyikan apa yang diciptakan Allah dalam rahimnya..." (Q.S. al-Baqarah [2]: 288).

Padahal kata qurù bersifat ambigu atau mushtarakah (mempunyai arti lebih dan satu). Kata tersebut dapat berarti menstruasi (hayd) dan dapat pula berarti dalam keadaan suci (tuhr). 'Umar ibn al-Khațtāb, 'Ali ibn Abi T⿳ălib, ibn Mas'ūd, dan Abū Mūsa al-Ash'ari, menafsirkan kata "aqra", yakni bentuk tunggal (mufrad) dan kata qurū' itu dengan tafsiran menstruasi (hayd). Tafsiran ini dipegangi pula oleh Sa'id al-Musayyab, Ața', dan beberapa kelompok täbi'in serta sejumlah ahli hukum. Sementara itu, 'Aishah, Zayd ibn Thabit dan Ibnu 'Umar diriwayatkan bahwa mereka menafsirkan kata "aqra" yang terdapat pada ayat di atas dengan tafsiran masa suci serta di antara menstruasi (athar). ${ }^{18}$

${ }^{18}$ Lihat Badri Khaeruman, Sejarah Perkembangan Tafsir al-Qur'an (Bandung: Pustaka Seni, 2004).
Perbedaan tafsiran mengenai ayat hukum di atas menyebabkan perbedaan dalam penentuan 'iddah bagi wanita yang dicerai. Menurut tafsiran pertama, masa menunggu bagi wanita yang dicerai ('iddah) itu adalah setelah selesai menstruasi ketiga. Sedangkan menurut tafsiran kedua, 'iddah selesai dengan dimulainya menstruasi ketiga.

Jadi, tafsiran pertama mengharuskan wanita menyelesaikan masa 'iddah-nya itu selama tiga bulan penuh. Sedangkan tafsiran kedua menyatakan tidak harus selama tiga bulan penuh, yakni cukup pada waktu dimulai menstruasi ketiga saja. Bahkan Hadits da'if menyatakan bahwa 'iddah wanita yang dicerai itu cukup dua kali menstruasi saja.

Ketentuan 'iddah ini 'illat hukumnya untuk mengetahui apakah wanita yang dicerai itu sedang mengandung janin dari suaminya atau tidak dalam keadaan mengandung. Jika diketahui sedang mengandung, 'Umar bin Khattab melarang suami menceraikan istrinya dalam keadaan mengandung. Jika pun harus terpaksa bercerai, maka 'iddah wanita yang dicerai dalam keadaan mengandung itu adalah hingga melahirkan. 'Illat tersebut sesungguhnya sudah bisa diketahui melalui bantuan teknologi kedokteran atau alat USG, apakah wanita itu mengandung atau tidak mengandung, dengan tidak harus menunggu hingga tiga kali qurū'. Namun hikmah di balik ketentuan itu, bisa jadi Tuhan masih memberi kesempatan kepada pasangan yang bercerai itu untuk bisa kembali lagi sebagai suami istri sebagaimana semula. Namun jika perceraian itu telah tiga kali dilakukan di mana telah terjadi talaq ba'inn, yang tentunya tidak bisa kembali menikah, maka dengan bantuan teknologi kedokteran atau alat USG untuk mengetahui apakah istri yang dicerai itu dalam keadaan hamil atau tidak hamil, sepertinya tidak perlu menunggu hingga tiga kali menstruasi, melainkan cukup satu kali saja untuk membuktikan kebenaran diagnosis kedokteran yang menyatakan ketidak-hamilan perempuan yang dicerai itu. Tentu kecanggihan alat kedokteran ini akan berhadapan dengan teks ayat yang menyatakan tiga kali 
qurū'seperti di atas, yang sesungguhnya 'illat hukumnya untuk mengetahui keadaan rahim wanita yang dicerai itu apakah dalam keadaan hamil atau tidak hamil.

Dalam fatwa tersebut terlihat bahwa alQaraḍāwi mendukung kemajuan teknologi kedokteran. Karena itu seharusnya pula ketetapan tentang masa 'iddah wanita yang dicerai itu pun yang 'illat-nya untuk mengetahui hamil dan tidaknya wanita yang dicerai itu tidak bisa secara mutlak ditentukan harus selama tiga kali haid. Karena rahasia rahim wanita yang menjadi 'illat bagi masa 'iddah telah diketahui secara gamlang oleh teknologi kedokteran. Lagi pula bagi manusia modern sekarang yang lebih rasional, dalam memutuskan untuk bercerai biasanya didahului dengan proses pisah ranjang yang berbulanbulan, yang tentunya tidak melakukan persetubuhan $(j u n \bar{u} b)$ antara pasangan itu, yang bisa menyebabkan kehamilan. Namun tampaknya al-Qaradāwi tidak berani mengabaikan ketentuan Alquran tentang masa 'iddah ini. Dia berhenti di situ dalam pernyataannya yang terbatas dengan menyatakan: mendukung kemajuan teknologi.

Contoh pemikiran-pemikiran al-Qaraḍāwi tersebut di atas merupakan wacana bagi reformasi pemikiran di bidang hukum Islam di masa mendatang, yang lebih arif dan bijaksana sebagai respon positif atas berbagai kemajuan teknologi yang telah dicapai manusia modern, terutama yang dialami dunia Barat dewasa ini, yang imbasnya tentu dialami pula oleh masyarakat Muslim di mana pun berada.

Sebetulnya masih banyak contoh yang menarik untuk diungkap dari pemikiran alQaraḍāwi di atas, namun sesuai dengan bahasannya, contoh nampaknya tidak harus banyak-banyak diungkap.

\section{SIMPULAN}

Al-Qaraḍāwi memandang bahwa 'illat hukum secara alami akan terus berubah dan bahkan bisa kembali kepada asalnya semula, seiring perkembangan dan perubahan situasi dan kondisi zaman. Oleh karena itu, pemikiran hukum pun perlu mengalami pembaruan dan perumusan ulang seiring dengan munculnya kebutuhan-kebutuhan sosial akan fatwa-fatwa dan pertimbangan-pertimbangan hukum baru, sekalipun teks hukum tidak boleh berubah. Sejak dulu, para ulama fiqh telah mengusulkan bahwa hukum akan berlaku bersama 'illat hukum itu sendiri (alhukm yaduru ma'a 'illatihi). Dan, inilah juga yang menjadi pegangan al-Qaradāâi.

Dalam rangka merumuskan fatwa-fatwa hukum baru sebagai upaya pemenuhan kebutuhan sosial akan fatwa-fatwa tersebut, al-Qaraḍāwi mengusulkan dua metode penggalian (ijtihad) hukum, yakni intiqāi dan inshai. Kedua metode ini merupakan kontribusi al-Qaradāwi bagi pengembangan pemikiran hukum Islam kontemporer saat ini, yang tentunya memberikan manfaat yang sangat besar, baik dari segi metode maupun substansi pengembangan pemikiran hukum, antara lain sebagai berikut:

1. Adanya metode intiq $\bar{a} \bar{i}$ dan inshai, yang kemudian disusul dengan lahirnya fatwafatwa Al-Qaradāwi yang merespon munculnya illat baru dalam hukum Islam sebagai akibat dari adanya kemajuan zaman, maka dari aspek pengembangan ilmu Sharī'at, pemikiran Al-Qaraḍāwi di atas sangat relevan dengan kebutuhan kehidupan umat Islam dewasa ini yang semakin kompleks dan membutuhkan justifikasi baru atas berbagai persoalan baru maupun persoalan lama dengan kondisi dan 'illat yang baru.

2. Dari aspek teori, metode intiqai dan inshai mampu menghilangkan perbedaan madzhab, baik perbedaan madzhab empat yang dominan dalam internal Sunni, maupun perbedaan antar Sunni-Shi'’ah. Karena dalam praktik dua metode tersebut, sebelum mengambil istinbat hukum, terlebih dahulu diharuskan menggali khazanah hukum yang telah ada dalam fiqh terdahulu, baik yang ada dalam fiqh Sunni maupun Shi'ah. Dengan begitu, kedua metode tersebut akan mampu 
menggabungkan seluruh prinsip fiqh yang ada, yang terkadang berbeda-beda.

3. Munculnya dua metode tersebut, tentu akan melahirkan kaidah Ushūl yang baru, atau menguatkan kembali kaidah lama sesuai dengan adanya 'illat baru atas hukum itu.

4. Adanya nilai-nilai komprehensif, yang terkandung dalam metode intiq $\bar{a} \bar{i}$ dan inshäi ini, jelas menempatkan perubahan sosial sebagai wujud dari kemajuan teknologi dewasa ini, bukan merupakan ancaman bagi keterasingan hukum Islam di tengahtengah kehidupan masyarakat, melainkan sebagai anugerah kehidupan yang harus disyukuri. Karena kemajuan identik dengan kemudahan.

5. Terkait dengan kontribusi Al-Qaraḍāwi bagi pengembangan ilmu berfatwa, terutama berkaitan dengan penentuan 'illat (masālik al-'illat) sehingga fatwa itu kemudian diputuskan, Al-Qaraḍāwi mengisyaratkan berpegang pada rumusan yang telah dibuat oleh para ahli Ushūl yang menetapkan sekurang-kurangnya tiga cara, yaitu: memutuskan fatwa dengan nash alKitāb dan Sunah, Ijmā' dan al-Munāsabah, yakni penetapan 'illat yang cocok dan memang terdapat persesuaian ketika dihubungkan dengan penetapan hukum itu padanya.

Terakhir, berkaitan dengan orientasi pemikiran hukum Islam dalam menjawab perubahan sosial dan kebutuhan akan fatwafatwa hukum baru, al-Qardāwi berpihak kepada sikap dan pandangan hukum yang moderat, dan yang berpegang pada prinsip "memberi kemudahan" (taysirir) dan kabar gembira, serta prinsip pemaduan antara pandangan salafiyah (Alquran dan Sunah) dan pembaruan (tajdid).

\section{DAFTAR PUSTAKA}

Al-Jauziyah, Ibn Qayyim. I'lam al-Muwaqi'in 'an Rabb al-'Alamin. Beirut: Dar al-Fikr, 1977.

Al-Qaraḍ̄āi, Yūsuf. Faktor-faktor Pengubah Fatwa. Jakarta: Pustaka al-Kautsar, 2009. - Taysir al-Fiqh li al-Muslim alMu'āshir. Kairo: Maktabah Wahbah, 1999.

Al-Shāfi'i, Imam. al-Umm. Diedit oleh Mahmud Matraji. Beirut: Dār al-Kutub al-Ilmiah, 2009.

Al-Syaukani, Muhammad bin Ali. "hadits No. 390," t.t.

Al-Ṭūî. Risalah fí Ri'àyat al-Maslahah. Diedit oleh Ahmad Abd al-Rahim Sayikh. Mesir: al-Dār al-Misriyah alLubnaniyah, 1993.

Al-Zuhaili, Wahbah. Ușūl al-Fiqh al-Islāmi. Beirut: Dār al-Fikr, 1986.

Dirdjosiswono, Sodjono. Sosiologi Hukum. Jakarta: CV. Rajawali, 1983.

Halawi, Muhammad Abd al-'Aziz al-. Fatawa wa Aqdhiyat Amiril Mukminin 'Umar ibn al-Khattāab, terj. Zubeir Suryadi Abdullah. Surabaya: Risalah Gusti, 1999.

Khaeruman, Badri. Sejarah Perkembangan Tafsir al-Qur'an. Bandung: Pustaka Seni, 2004.

Manan, Abdul. Aspek-aspek Pengubah Hukum. Jakarta: Kencana, 2006.

\section{Internet}

Sulis Syakhsiyah Annisa, "Hukum Islam dan Perubahan Sosial," 2009. Diakses tanggal 14 Juni 2015. https://syakhsiyah wordpress.com/2009/08/12/110/ftn8.

Siddiq, M. "Menyoal fiqih Waqi Fikih Realitas," 2010. http://syabab1924.blogspot.co.id/2010/0 9/menyoal-fiqih-waqi-fikih-realitas.html. 